\title{
Sanitasi, infeksi, dan status gizi anak balita di Kecamatan Tenggarong Kabupaten Kutai Kartanegara
}

Sanitation, infection and nutrition status of underfives at Subdistrict of Tenggarong District of Kutai Kartanegara

Andi Tenri Abeng ${ }^{1}$, Djauhar Ismail ${ }^{2}$, Emy Huriyati ${ }^{3}$

\begin{abstract}
Background: Malnutrition is a public health problem commonly encountered in developing countries. Almost $50 \%$ of $10-11$ millions of mortality among children under-fives caused by malnutrition that are preventable. District of Kutai Kartanegara is known as the most wealth of district in Indonesia, yet the wealth cannot automatically solve the problem of its people. Numerous efforts have been made to solve malnutrition problem yet the morbidity rate is still relatively high. Objective: The study aimed to identify association between sanitation with infection and nutritional status of underfives at Subdistrict of Tenggarong, District of Kutai Kartanegara. Method: The study was observational with cross sectional design. Samples consisted of 187 underfives of 7-60 months taken using proportional random sampling technique. Variable of sanitation was obtained from interview with subjects using questionnaire and direct observation. Variable of infection was obtained from interview with subjects and cross check at health centers. The dependent variable of nutritional status was based on anthropometric assessment using weight/height index. Bivariate analysis used Chi-Square and multivariate analysis used logistic regression. Results: The result of statistical test showed there was significant association between sanitation and infection (acute respiratory tract infection/ARI, diarrhea) of underfives $(p<0.05)$. There was association between ARI and diarrhea with wasted children $(p<0.05)$. Conclusion: There was significant association between sanitation, infection and nutritional status of underfives at Subdistrict of Tenggarong District of Kutai Kartanegara.
\end{abstract}

KEY WORDS: environmental sanitation, infection disease, nutrition status, underfives

\begin{abstract}
ABSTRAK
Latar belakang: Kurang gizi adalah masalah kesehatan masyarakat yang terjadi di negara berkembang, 50\% dari 10-11 juta anak balita setiap tahun meninggal dengan sebab-sebab yang seharusnya dapat dicegah. Kabupaten Kutai Kartanegara dikenal sebagai kabupaten terkaya tetapi kekayaan tersebut belum bisa mengatasi masalah penduduknya. Hal ini ditunjukkan dengan ditemukannya kasus gizi kurang dan gizi buruk di semua wilayah Kabupaten Kutai Kartanegara. Berbagai upaya telah dilakukan untuk mengatasi masalah gizi tetapi angka kesakitan masih tinggi. Tujuan: Mengetahui hubungan antara sanitasi lingkungan dan penyakit infeksi dengan status gizi balita di Kecamatan Tenggarong Kabupaten Kutai Kartanegara. Metode: Jenis penelitian observasional dengan desain cross sectional. Sampel adalah balita usia 7-60 bulan sejumlah 187 sampel yang diambil dengan metode proporsional random sampling. Variabel sanitasi lingkungan diperoleh dari wawancara dengan subjek menggunakan kuesioner dan observasi langsung. Variabel penyakit infeksi diperoleh dari wawancara kemudian dilakukan cross check di puskesmas. Variabel terikat status gizi ditentukan berdasarkan pengukuran antropometri dengan menggunakan indikator berat badan per tinggi badan (BB/TB). Analisis bivariat menggunakan uji Chi-Square dan multivariat menggunakan regresi logistik. Hasil: Terdapat hubungan yang signifikan antara sanitasi lingkungan dengan penyakit infeksi (ISPA, diare) pada balita $(\mathrm{p}<0,05)$. Demikian juga dengan penyakit infeksi dengan status gizi balita $(\mathrm{p}<0,05)$. Uji regresi logistik menunjukkan variabel yang dominan mempengaruhi status gizi adalah penyakit infeksi (ISPA, diare) dan asupan protein. Simpulan: Sanitasi lingkungan dan penyakit infeksi berhubungan signifikan dengan status gizi balita di Kecamatan Tenggarong Kabupaten Kutai Kartanegara.
\end{abstract}

KATA KUNCI: sanitasi lingkungan, penyakit infeksi, status gizi balita

\section{PENDAHULUAN}

Status gizi merupakan salah satu faktor yang dapat menentukan kualitas sumber daya manusia. Indonesia termasuk di antara 36 negara di dunia yang memberi $90 \%$ kontribusi masalah gizi dunia. Pada tahun 2007, prevalensi anak balita yang mengalami gizi kurang sebesar $18,4 \%$; gizi buruk sebesar 5,4\%; dan pendek
36,8\% (1). Selanjutnya, data Riset Kesehatan Dasar (Riskesdas) tahun 2010 menunjukkan bahwa prevalensi

\footnotetext{
Korespondensi: Dinas Kesehatan Kabupaten Maros, Jl. Bougenvile Kompleks Kantor Bupati Maros, e-mail: Tenriabengandi@yahoo.co.id

2 Bagian Ilmu Kesehatan Anak, Rumah Sakit Umum Pusat (RSUP) Dr. Sardjito, Jl. Kesehatan No. 1, Sekip, Yogyakarta 55284

3 Program Studi Gizi Kesehatan, Fakultas Kedokteran Universitas Gadjah Mada, Jl. Farmako, Sekip Utara, Yogyakarta 55281,e-mail: emy_huriyati@yahoo.
} com 
gizi kurang sebesar 17,9\%; gizi buruk 4,9\%; dan pendek $35,6 \%$ yang meningkat menjadi masing-masing $19,6 \%$; $5,7 \%$; dan 37,2\% pada tahun 2013 (2). Kecenderungan ini menunjukkan bahwa target penurunan prevalensi gizi kurang dan gizi buruk menjadi $15,5 \%$ dan 3,5\% pada tahun 2015 sulit tercapai.

Kabupaten Kutai Kartanegara dikenal sebagai kabupaten terkaya di Indonesia tetapi kekayaan itu ternyata belum bisa mengatasi masalah penduduknya. Hal ini ditunjukkan dengan ditemukannya kasus gizi kurang dan gizi buruk di semua wilayah meskipun prevalensinya di tingkat kabupaten masih rendah dibandingkan dengan prevalensi nasional. Prevalensi kasus gizi kurang dan gizi buruk di Kabupaten Kutai Kartanegara bervariasi dari tahun ke tahun yaitu berturut-turut pada tahun 2010 sebesar $15,14 \%$ dan 2,42\%; tahun 2011 sebesar $6,13 \%$ dan 0,93\%; tahun 2012 sebesar $4,48 \%$ dan $2,08 \%$ sedangkan pada tahun 2013 ditemukan sebesar 9,53\% dan 4,06\% (3).

Informasi di atas menunjukkan bahwa prevalensi kurang gizi berubah setiap saat. Keadaan ini perlu disadari karena terjadinya masalah gizi sangat terkait dengan berbagai faktor yang mempengaruhi antara lain adanya penyakit infeksi seperti diare, tuberkulosis paru, infeksi saluran pernapasan akut (ISPA), demam berdarah dengue (DBD), malaria, dan lain-lain yang terkait dengan faktor sanitasi lingkungan. Keadaan sanitasi lingkungan yang kurang baik juga memungkinkan terjadinya berbagai jenis penyakit infeksi yang akhirnya dapat mempengaruhi status gizi. Sanitasi lingkungan sangat terkait dengan ketersediaan air bersih, ketersediaan jamban, jenis lantai rumah serta kebersihan peralatan makan pada setiap keluarga. Semakin tersedia air bersih untuk kebutuhan sehari-hari, semakin kecil risiko anak untuk terkena penyakit kurang gizi (4).

Dari hasil pemantauan sanitasi puskesmas dan laporan subdin penyehatan lingkungan Dinas Kesehatan Kabupaten Kutai Kartanegara, cakupan air bersih tahun 2006 sebesar 36,49\% dan tahun 2008 sebesar 28,53\%. Masalah cakupan air bersih masih rendah dan masih jauh dari target Millennium Development Goals (MDGs) yaitu sebesar 70\% di tahun 2015 (5). Berdasarkan profil kesehatan Dinas Kesehatan Kabupaten Kutai Kartanegara tahun 2011-2013, format pelaporan untuk menilai keadaan sanitasi lingkungan mengalami perubahan, indikator yang digunakan adalah rumah sehat, tempat umum dan pengelolaan makanan sehat, serta sarana air bersih. Cakupan rumah sehat dari tahun 2011 hingga tahun 2013 tidak mengalami perubahan yaitu 54\%. Sementara itu, cakupan tempat umum dan pengelolaan makanan yang memenuhi syarat kesehatan pada tahun 2011 sebesar 67,95\% sedangkan tahun 2012 mengalami penurunan yaitu $56,13 \%$ tetapi meningkat lagi menjadi $63,21 \%$ pada tahun 2013. Cakupan sarana air bersih berturut-turut dari tahun 2011 hingga tahun 2013 masingmasing sebesar 37\%; 65,6\%; dan 47,8\%. Pencapaiannya masih jauh dari target MDGs hingga tahun 2015.

Berdasarkan data sepuluh penyakit terbesar di Kabupaten Kutai Kartanegara pada tahun 2007-2009, penyakit infeksi masih menduduki urutan pertama dan prevalensinya meningkat setiap tahun. Penyakit infeksi tersebut adalah ISPA sebesar 13\% dan diare sebesar 5,8\% kemudian meningkat menjadi $19,9 \%$ untuk prevalensi ISPA dan 7,1\% diare pada tahun 2008 sedangkan prevalensi pada tahun 2009 yaitu ISPA $21,3 \%$ dan diare 10,7\%. Bahkan, pada tahun 2011-2013 kembali terjadi peningkatan prevalensi ISPA dan diare yaitu berturutturut sebesar $21,2 \% ; 23,5 \%$; dan $25,7 \%$ untuk ISPA dan prevalensi diare sebesar 45,1\% sedangkan tahun 2012 dan 2013 tidak mengalami perubahan yaitu sebesar 27,3\% (6).

Menurut latar belakang tersebut, perlu dilakukan penelitian ini yang bertujuan untuk mengetahui hubungan antara sanitasi lingkungan dan penyakit infeksi dengan status gizi anak balita di Kecamatan Tenggarong Kabupaten Kutai Kartanegara.

\section{BAHAN DAN METODE}

Penelitian ini merupakan studi observasional dengan rancangan cross sectional. Penelitian dilaksanakan selama 3 bulan yaitu mulai bulan Desember 2010 sampai dengan Februari 2011. Populasi penelitian adalah balita yang bertempat tinggal di Kecamatan Tenggarong Kabupaten Kutai Kartanegara yang berjumlah 8.537 orang. Sampel penelitian yaitu balita usia 7-60 bulan yang memenuhi kriteria inklusi dan ekslusi. Kriteria inklusi meliputi balita usia 7-60 bulan, balita termuda dari keluarga yang memiliki 
lebih dari satu balita, dan ibu balita bersedia menjadi subjek penelitian. Kriteria ekslusi yaitu anak dengan berat badan lahir rendah (BBLR) dan menderita kelainan kongenital atau cacat fisik. Besar sampel dihitung berdasarkan rumus besar sampel untuk survei sampel (7) dengan tingkat kepercayaan 95\%; presisi (d) sebesar 0,05; proporsi sampel (P) sebesar 0,145; dan besar populasi (N) adalah 8.537 sehingga diperoleh besar sampel pada penelitian ini yaitu 187 balita. Jumlah sampel tersebut didistribusi secara proporsional pada 3 puskesmas yang ada di Kecamatan Tenggarong yaitu Puskesmas Rapak Mahang sebanyak 75 anak, Puskesmas Mangkurawang 52 anak, dan Puskesmas Loa Ipuh 60 anak.

Variabel yang diteliti dalam penelitian ini meliputi variabel bebas yaitu sanitasi lingkungan, variabel terikat adalah status gizi balita, variabel antara yaitu penyakit infeksi (ISPA, diare), serta variabel luar yaitu asupan makanan dan pola asuh. Data yang dikumpulkan meliputi karakteristik subjek dan keluarga subjek; sanitasi lingkungan diperoleh melalui wawancara dan pengamatan langsung; penyakit infeksi diperoleh melalui wawancara dengan subjek (ibu balita) dan dilakukan cross check di puskesmas; berat badan subjek diukur dengan dacin; panjang badan subjek usia 7-24 bulan diukur menggunakan alat ukur panjang badan sedangkan tinggi badan subjek usia 25-60 bulan diukur dengan microtoise; status gizi diperoleh melalui perhitungan indeks berat badan per tinggi badan (BB/TB); serta formulir recall 24 jam untuk mengukur asupan zat gizi anak balita yang dihitung selama 3 hari tidak berturut-turut yaitu berselang dua hari dengan mengambil 2 hari kerja dan 1 hari libur dengan tujuan untuk melihat variasi makanan keluarga dalam satu minggu (8).

Sanitasi lingkungan yaitu keadaan faktor-faktor lingkungan fisik dan biologi yang memenuhi syarat kesehatan yang diukur dari ketersediaan air bersih, ketersediaan jamban, ketersediaan saluran pembuangan air limbah (SPAL), kondisi rumah, dan perilaku penghuni rumah (9). Kuesioner terdiri dari 20 pertanyaan, apabila benar mendapat skor 1 dan jika salah mendapat skor 0 . Skor tersebut kemudian dijumlahkan dan dikategorikan menjadi memenuhi syarat kesehatan bila skor lebih dari atau sama dengan $60 \%$. Status gizi diukur secara antropometri dengan menggunakan perhitungan z-score dari indikator BB/TB yang dikategorikan kurus (wasted jika z-score $<-2,0 \mathrm{SD}$ ) dan normal (z-score $\geq-2,0 \mathrm{SD}$ ) (10).

Penyakit infeksi adalah penyakit yang pernah diderita anak dalam satu bulan terakhir atau pada saat dilaksanakannya penelitian berdasarkan diagnosis dokter atau bidan pada kartu register pasien (11). Dikategorikan ada infeksi apabila balita pernah menderita penyakit infeksi (ISPA, diare) dalam kurun waktu satu bulan terakhir. Asupan makanan merupakan jumlah makanan yang dikonsumsi subjek dalam satuan gram dan dikonversi menjadi energi (kkal) dan protein ( $\mathrm{g}$ ) kemudian dikategorikan menjadi cukup (80-110\% AKG) dan kurang ( $<80 \%$ AKG) (12). Pola asuh yang dimaksud dalam penelitian ini adalah perilaku atau kebiasaan yang diberikan ibu atau pengasuh lain dari balita dalam hal pemberian ASI dan makanan (13). Pola asuh diukur berdasarkan kuesioner terstruktur yang terdiri dari 30 pertanyaan, apabila benar mendapat skor 1 dan jika salah mendapat skor 0. Skor tersebut kemudian dijumlahkan dan dikategorikan menjadi baik bila skor lebih dari atau sama dengan $60 \%$.

Data yang dikumpulkan kemudian dianalisis secara bertahap yaitu analisis univariat, bivariat, dan multivariat. Analisis bivariat menggunakan uji statistik Chi-Square dan Fisher's exact test sedangkan analisis multivariat menggunakan uji regresi logistik. Penelitian ini telah mendapat persetujuan etik dari Komite Etik Fakultas Kedokteran Universitas Gadjah Mada.

\section{HASIL}

\section{Karakteristik subjek}

Jumlah balita yang menjadi subjek penelitian sebanyak 187 orang yang terdiri dari 91 anak laki-laki $(48,7 \%)$ dan 96 anak perempuan (51,3\%). Kelompok umur 12-36 bulan merupakan jumlah yang paling banyak $(64,2 \%)$ dan tempat pencarian pengobatan yang paling banyak dikunjungi adalah puskesmas (54,5\%) dan tempat praktik bidan atau dokter $(32,1 \%)$ (Tabel 1). Anggota keluarga subjek sebagian besar $(84,0 \%)$ berjumlah kurang dari 6 orang. Kelompok umur ayah paling banyak pada usia 31-40 tahun $(56,1 \%)$ sedangkan kelompok umur ibu pada usia 21-30 tahun (51,9\%). Pendidikan terakhir ayah dan ibu balita lebih banyak pada tingkat 
Tabel 1. Karakteristik subjek penelitian $(n=187)$

\begin{tabular}{lcc}
\hline Karakteristik & $\mathbf{n}$ & $\mathbf{\%}$ \\
\hline Jenis kelamin & & \\
Laki-laki & 91 & 48,7 \\
Perempuan & 96 & 51,3 \\
Usia (bulan) & & \\
$7-11$ & 22 & 11,8 \\
$12-36$ & 120 & 64,2 \\
$37-60$ & 45 & 24,1 \\
Jumlah balita & & \\
$<2$ & 177 & 94,7 \\
$>2$ & 10 & 5,3 \\
Tempat pengobatan & & \\
Puskesmas & 102 & 54,5 \\
Rumah sakit & 3 & 1,6 \\
Dukun & 1 & 0,5 \\
Diobati sendiri & 21 & 11,2 \\
Lainnya (Bidan/dokter praktek) & 60 & 32,1 \\
\hline
\end{tabular}

Tabel 2. Distribusi variabel penelitian

\begin{tabular}{lcc}
\hline \multicolumn{1}{c}{ Karakteristik } & n & \% \\
\hline Sanitasi lingkungan & & \\
$\quad$ Tidak memenuhi syarat & 113 & 60,4 \\
$\quad$ Memenuhi syarat & 74 & 39,6 \\
Infeksi diare & & \\
$\quad$ Diare & 25 & 13,4 \\
$\quad$ Tidak diare & 162 & 86,6 \\
Infeksi ISPA & & \\
ISPA & 86 & 46,0 \\
$\quad$ Tidak ISPA & 101 & 54,0 \\
Status gizi & & \\
$\quad$ Kurus (wasted) & 95 & 50,8 \\
$\quad$ Normal & 92 & 49,2 \\
Asupan energi & & \\
$\quad$ Kurang & 144 & 77,0 \\
Cukup & 43 & 23,0 \\
Asupan protein & & \\
$\quad$ Kurang & 100 & 53,5 \\
Cukup & 87 & 46,5 \\
Pola asuh & & \\
$\quad$ Kurang & 101 & 54,0 \\
Baik & 86 & 46,0 \\
\hline
\end{tabular}

sekolah menengah atas (SMA) $(51,3 \%$ dan $44,4 \%)$. Pekerjaan ayah lebih didominasi oleh wiraswasta $(52,9 \%)$ sedangkan ibu lebih banyak yang tidak bekerja (70,1\%). Distribusi variabel penelitian pada Tabel 2 menunjukkan bahwa sebagian besar subjek penelitian berada dalam sanitasi lingkungan yang tidak memenuhi syarat, tidak diare, tidak ISPA, status gizi kurus, asupan energi dan protein kurang, serta pola asuh yang kurang.

\section{Hubungan sanitasi dengan penyakit infeksi (diare dan ISPA)}

Tabel 3 menunjukkan bahwa dari 187 subjek, balita yang menderita diare dari sanitasi lingkungan yang tidak memenuhi syarat sebanyak $20,4 \%$ sedangkan yang menderita diare dari lingkungan yang memenuhi syarat sebanyak 2,7\%. Hasil analisis menunjukkan hubungan signifikan antara sanitasi lingkungan yang tidak memenuhi syarat dengan kejadian diare $(p=0,00)$. Anak dari keluarga dengan sanitasi lingkungan yang tidak memenuhi syarat berpotensi menderita diare 9 kali lebih besar dibanding dengan anak dari keluarga yang sanitasi lingkungannya memenuhi syarat.

Sementara itu, Tabel 4 menunjukkan bahwa dari 187 subjek, sebanyak 61,9\% subjek yang menderita ISPA dari sanitasi lingkungan yang tidak memenuhi syarat sedangkan 21,6\% subjek menderita ISPA dari lingkungan yang memenuhi syarat. Hasil analisis menunjukkan hubungan signifikan antara sanitasi lingkungan yang tidak memenuhi syarat dengan kejadian ISPA $(p=0,00)$. Anak dari keluarga dengan sanitasi lingkungan yang tidak memenuhi syarat berpotensi menderita ISPA 6 kali lebih besar dibandingkan dengan anak dari keluarga yang sanitasi lingkungannya memenuhi syarat.

\section{Hubungan penyakit infeksi dengan status gizi balita}

Berdasarkan Tabel 5 dapat diketahui bahwa balita yang berstatus gizi kurus dan menderita infeksi diare sebanyak 92\%. Hasil analisis menunjukkan hubungan signifikan antara infeksi diare dengan status gizi balita $(\mathrm{p}=0,00)$. Anak yang menderita diare berpeluang 14,37 kali berstatus gizi kurus dibandingkan dengan anak yang tidak diare. Penelitian ini sejalan dengan penelitian di Kabupaten Hulu Sungai selatan yang menunjukkan adanya hubungan yang bermakna antara infeksi diare dengan perubahan status gizi pada baduta (14). Demikian juga pada infeksi ISPA, diketahui bahwa subjek berstatus gizi kurus sebanyak 72,1\% yang menderita ISPA dan 32,7\% tidak menderita ISPA. Hasil analisis menunjukkan hubungan signifikan antara infeksi ISPA 
Tabel 3. Hubungan sanitasi lingkungan dengan infeksi diare

\begin{tabular}{|c|c|c|c|c|c|c|c|c|}
\hline \multirow{3}{*}{ Sanitasi lingkungan } & \multicolumn{4}{|c|}{ Infeksi diare } & \multirow{2}{*}{\multicolumn{2}{|c|}{ Total }} & \multirow{3}{*}{$\begin{array}{c}\text { OR } \\
(95 \% \mathrm{Cl})\end{array}$} & \multirow{3}{*}{$\mathbf{p}$} \\
\hline & \multicolumn{2}{|c|}{ Diare } & \multicolumn{2}{|c|}{ Tidak diare } & & & & \\
\hline & $\mathbf{n}$ & $\%$ & $\mathbf{n}$ & $\%$ & $\mathbf{n}$ & $\%$ & & \\
\hline Tidak memenuhi syarat & 23 & 20,4 & 90 & 79,6 & 133 & 100 & 9,2 & $0,00^{*}$ \\
\hline Memenuhi syarat & 2 & 2,7 & 72 & 97,3 & 74 & 100 & $(2,09-40,33)$ & \\
\hline Jumlah & 25 & 13,4 & 162 & 86,6 & 187 & 100 & & \\
\hline
\end{tabular}

Keterangan: * bermakna $(\mathrm{p}<0,05 ;$ Fisher's exact test $)$

Tabel 4. Hubungan sanitasi lingkungan dengan infeksi ISPA

\begin{tabular}{|c|c|c|c|c|c|c|c|c|}
\hline \multirow{3}{*}{ Sanitasi lingkungan } & \multicolumn{4}{|c|}{ Infeksi ISPA } & \multirow{2}{*}{\multicolumn{2}{|c|}{ Total }} & \multirow{3}{*}{$\begin{array}{c}\text { OR } \\
(95 \% \mathrm{Cl})\end{array}$} & \multirow{3}{*}{$\mathbf{p}$} \\
\hline & \multicolumn{2}{|c|}{ ISPA } & \multicolumn{2}{|c|}{ Tidak ISPA } & & & & \\
\hline & $\mathbf{n}$ & $\%$ & $\mathbf{n}$ & $\%$ & $\mathbf{n}$ & $\%$ & & \\
\hline Tidak memenuhi syarat & 70 & 61,9 & 43 & 38,1 & 113 & 100 & 5,9 & $0,00^{*}$ \\
\hline Memenuhi syarat & 16 & 21,6 & 58 & 78,4 & 74 & 100 & $(3,02-11,55)$ & \\
\hline Jumlah & 86 & 46,0 & 101 & 54,0 & 187 & 100 & & \\
\hline
\end{tabular}

Keterangan: * bermakna $(\mathrm{p}<0,05 ;$ Chi-Square $)$ ISPA $=$ infeksi saluran pernafasan akut

Tabel 5. Hubungan penyakit infeksi dengan status gizi balita

\begin{tabular}{|c|c|c|c|c|c|c|c|c|}
\hline \multirow{3}{*}{ Penyakit infeksi } & \multicolumn{4}{|c|}{ Status gizi } & \multirow{2}{*}{\multicolumn{2}{|c|}{ Total }} & \multirow{3}{*}{$\begin{array}{c}\text { OR } \\
(95 \% \mathrm{Cl})\end{array}$} & \multirow{3}{*}{$\mathbf{p}$} \\
\hline & \multicolumn{2}{|c|}{ Kurus } & \multicolumn{2}{|c|}{ Normal } & & & & \\
\hline & $\mathbf{n}$ & $\%$ & $\mathbf{n}$ & $\%$ & n & $\%$ & & \\
\hline \multicolumn{9}{|l|}{ Infeksi diare } \\
\hline Diare & 23 & 92,0 & 2 & 8,0 & 25 & 100 & 14,37 & $0,00 *$ \\
\hline Tidak diare & 72 & 44,4 & 90 & 55,6 & 162 & 100 & $(3,28-63,01)$ & \\
\hline \multicolumn{9}{|l|}{ Infeksi ISPA } \\
\hline ISPA & 62 & 72,1 & 24 & 27,9 & 86 & 100 & 5,32 & $0,00 *$ \\
\hline Tidak ISPA & 33 & 32,7 & 68 & 67,3 & 101 & 100 & $(2,84-9,97)$ & \\
\hline Jumlah & 95 & 50,8 & 92 & 49,2 & 187 & 100 & & \\
\hline
\end{tabular}

Keterangan: * bermakna $(\mathrm{p}<0,05 ;$ Fisher's exact test $)$

dengan status gizi balita $(\mathrm{p}=0,00)$. Anak yang menderita ISPA berpotensi 5,32 kali lebih besar berstatus gizi kurus dibandingkan dengan anak tanpa infeksi ISPA.

\section{Hubungan variabel luar dengan status gizi balita}

Hasil analisis menunjukkan adanya hubungan antara asupan zat gizi dan pola asuh dengan status gizi pada balita $(\mathrm{p}=0,00)$ (Tabel 6). Berdasarkan analisis bivariat, variabel yang masuk analisis multivariat $(\mathrm{p} \leq 0,25)$ yaitu infeksi ISPA, infeksi diare, asupan energi, asupan protein, dan pola asuh. Pada Tabel 7 diketahui bahwa hasil analisis dengan regresi logistik menunjukkan variabel yang dominan mempengaruhi status gizi adalah penyakit infeksi (ISPA, diare) dan asupan protein.

\section{BAHASAN}

Hasil analisis menunjukkan hubungan yang signifikan antara sanitasi lingkungan dengan kejadian diare $(\mathrm{p}=0,001)$. Anak dari keluarga yang memiliki sanitasi lingkungan yang tidak memenuhi syarat berpotensi menderita diare 9 kali lebih besar dibandingkan anak dari keluarga yang sanitasi lingkungannya memenuhi syarat. Faktor risiko penyebab diare antara lain disebabkan oleh kurangnya air bersih, terjadinya kemarau panjang, sumber air yang tercemar, dan perilaku hidup bersih dan sehat (PHBS) masyarakat yang rendah. Faktor-faktor tersebut bisa mengakibatkan terjadinya kontaminasi atau pencemaran terhadap makanan (15). Penelitian sebelumnya menunjukkan bahwa sumber air dan praktek higiene mempunyai hubungan yang signifikan 
Tabel 6. Hubungan antara variabel luar dengan status gizi balita

\begin{tabular}{|c|c|c|c|c|c|c|c|c|}
\hline \multirow{3}{*}{ Asupan zat gizi } & \multicolumn{4}{|c|}{ Status gizi } & \multirow{2}{*}{\multicolumn{2}{|c|}{ Total }} & \multirow{3}{*}{$\begin{array}{c}\text { RP } \\
(95 \% \mathrm{Cl})\end{array}$} & \multirow{3}{*}{$\mathbf{p}$} \\
\hline & \multicolumn{2}{|c|}{ Kurus } & \multicolumn{2}{|c|}{ Normal } & & & & \\
\hline & $\mathbf{n}$ & $\%$ & $\mathbf{n}$ & $\%$ & n & $\%$ & & \\
\hline \multicolumn{9}{|l|}{ Asupan energi } \\
\hline Kurang & 89 & 61,8 & 55 & 38,2 & 144 & 100 & 9,97 & $0,00^{*}$ \\
\hline Cukup & 6 & 14,0 & 37 & 86,0 & 43 & 100 & $(3,95-25,19)$ & \\
\hline \multicolumn{9}{|l|}{ Asupan protein } \\
\hline Kurang & 78 & 78,0 & 22 & 22,0 & 100 & 100 & 14,59 & $0,00^{*}$ \\
\hline Cukup & 17 & 19,5 & 70 & 80,5 & 87 & 100 & $(7,17-29,71)$ & \\
\hline \multicolumn{9}{|l|}{ Pola asuh } \\
\hline Kurang & 63 & 62,4 & 38 & 37,6 & 101 & 100 & 2,79 & $0,00^{*}$ \\
\hline Baik & 32 & 37,2 & 54 & 62,8 & 86 & 100 & $(1,54-5,07)$ & \\
\hline Jumlah & 95 & 50,8 & 92 & 49,2 & 187 & 100 & & \\
\hline
\end{tabular}

Keterangan: * bermakna $(\mathrm{p}<0,05 ;$ Chi-Square $)$

Tabel 7. Hasil analisis multivariat regresi logistik

\begin{tabular}{lcc}
\hline \multicolumn{1}{c}{ Karakteristik } & $\mathbf{n}$ & $\mathbf{\%}$ \\
\hline Infeksi diare & 0,062 & $0,001^{*}$ \\
Infeksi ISPA & 0,208 & $0,000^{*}$ \\
Asupan energi & 0,290 & 0,072 \\
Asupan protein & 0,125 & $0,000^{*}$ \\
Pola asuh & 1,407 & 0,456 \\
\hline
\end{tabular}

Keterangan: * bermakna $(p<0,05)$

dengan kejadian diare pada anak. Jumlah kejadian diare lebih rendah pada rumah tangga dengan sumber air menggunakan air dari perpipaan atau keran dibandingkan rumah tangga yang menggunakan air sumur atau sungai yang tidak terlindungi. Selain itu, rumah tangga tanpa fasilitas toilet cenderung melaporkan penyakit diare yang terjadi pada anak mereka. Hal ini konsisten dengan penelitian di Eritrea (16) yang menunjukkan bahwa risiko menderita diare berhubungan signifikan dengan fasilitas toilet.

Demikian pula dengan infeksi ISPA yang menunjukkan hubungan signifikan dengan sanitasi lingkungan $(\mathrm{p}=0,00)$. Anak dari keluarga yang memiliki sanitasi lingkungan yang tidak memenuhi syarat, berpotensi menderita ISPA 6 kali lebih besar dibandingkan dengan anak dari keluarga yang sanitasi lingkungannya memenuhi syarat. Berdasarkan hasil pengamatan dan pengisian kuesioner, diketahui bahwa usaha penyediaan air minum oleh perusahaan air minum (PAM) belum menjangkau seluruh wilayah Kecamatan Tenggarong sehingga sebagian besar subjek masih menggunakan air sungai sebagai sumber air bersih. Bahkan, ada yang masih menggunakan penampungan air hujan yang tidak memenuhi persyaratan sebagai sumber air minum.

Sumber air bersih yang digunakan masyarakat, pada umumnya diperoleh dari perusahaan daerah air minum (PDAM) dan sumur gali. Namun, sebagian besar penduduk mempunyai kebiasaan menyimpan dan menampung air hujan untuk sumber air bersih di dalam gentong air, ember, drum-drum maupun bak-bak penampungan air lainnya sehingga dapat berpotensi terjadinya berbagai penyakit infeksi.

Kondisi lingkungan subjek yang masih tergolong buruk atau tidak memenuhi syarat kesehatan yaitu terletak pada masalah pengelolaan limbah, sampah, jamban, dan perumahan. Sebagian besar subjek tidak memiliki pengelolaan limbah yang baik. Limbah rumah tangga dibuang langsung ke sungai atau ke tempat terbuka dan biasanya langsung mencemari tanah. Hal ini tentu saja dapat menjadi media penyebaran berbagai penyakit terutama diare, media berkembangbiaknya mikroorganisme patogen, tempat berkembangbiaknya nyamuk, menimbulkan bau yang tidak enak serta pemandangan yang tidak sedap sekaligus sebagai sumber pencemaran air, permukaan tanah, dan lingkungan hidup lainnya (17).

Subjek yang tidak memiliki tempat sampah di rumah dan atau wilayahnya tidak terjangkau mobil pengangkut sampah, cenderung membuang sampah langsung ke sungai dan rawa atau lahan kosong di pekarangan rumah. Hal ini berefek negatif jika musim 
hujan tiba, sampah-sampah akan berserakan dan paling potensial sebagai media pertumbuhan berbagai kuman penyakit. Sementara itu, jenis jamban yang digunakan oleh sebagian besar subjek juga belum memenuhi syarat kesehatan. Masyarakat yang bermukim di atas sungai atau tinggal di pinggir sungai masih menggunakan jamban (WC) cemplung dan tidak memiliki septic tank. Bahkan, untuk memenuhi kebutuhan air bersih seperti untuk mandi dan mencuci juga berasal dari air sungai yang sama. Hal ini tentunya dapat mengancam kondisi kesehatan terutama bagi anak-anak sehingga diperlukan upaya-upaya untuk meningkatkan kualitas keadaan lingkungan tersebut.

Sumber air yang memadai tidak cukup menjamin bagi kesehatan jika tidak disertai dengan sanitasi dan pemanfaatan penampungan air yang baik. Anak dalam rumah tangga yang tidak memiliki tempat pembuangan sampah di rumahnya mempunyai $62 \%$ kemungkinan terkena penyakit infeksi dibandingkan anak dalam rumah tangga yang memiliki tempat pembuangan sampah. Kekurangan air dan sanitasi berkaitan dengan tingkat kesehatan pada masa anak-anak. Anak-anak dengan kondisi air dan sanitasi yang buruk meningkatkan risiko terserang diare. Pada usia 24 bulan, anak-anak dalam keadaan air dan sanitasi buruk memiliki kemungkinan terkena diare $54 \%$ dibandingkan anak-anak yang memiliki kondisi air yang lebih baik (18).

Higiene dan sanitasi lingkungan memiliki peranan yang cukup dominan dalam penyediaan lingkungan yang mendukung kesehatan anak balita dan tumbuh kembangnya. Kebersihan perorangan maupun lingkungan memegang peranan penting dalam timbulnya penyakit. Akibat dari kebersihan yang kurang adalah anak balita akan sering sakit, misalnya diare, kecacingan, tifus, hepatitis, demam berdarah, dan sebagainya. Apabila anak balita sering sakit, maka tumbuh kembangnya akan terganggu (19). Lebih lanjut, penyakit infeksi dalam tubuh akan membawa pengaruh terhadap keadaan gizi anak. Sebagai reaksi pertama adanya infeksi adalah menurunya nafsu makan anak sehingga anak menolak makanan yang diberikan oleh ibu atau pengasuhnya. Penolakan terhadap makanan berarti berkurangnya asupan zat gizi ke dalam tubuh anak yang akan menimbulkan gangguan gizi (20). Hasil analisis menunjukkan bahwa ada hubungan yang signifikan antara infeksi diare dengan status gizi balita $(p=0,00)$. Anak yang menderita diare berpeluang 14 kali lebih besar berstatus gizi kurus dibandingkan dengan anak yang tidak diare. Penelitian ini sejalan dengan penelitian sebelumnya yang menunjukkan adanya hubungan bermakna antara infeksi diare dengan perubahan status gizi pada baduta di Kabupaten Hulu Sungai Selatan (14)

Penyakit diare adalah penyebab utama kematian pada anak-anak di negara berkembang $(21,22)$. Di negara maju, meskipun kematian akibat diare dianggap bukan kejadian luar biasa, penyakit ini masih menjadi penyebab morbiditas dan memakan biaya perawatan kesehatan yang besar (23). Selain itu, terdapat beban kesehatan yang secara langsung ditimbulkan oleh penyakit diare meliputi malnutrisi, pertumbuhan terhambat, dan perkembangan kognitif yang tidak seimbang $(18,24)$. Hal ini didukung oleh penelitian sebelumnya yang membuktikan bahwa anak yang terkena infeksi diare pertumbuhannya akan lebih pendek, defisit kognitif, dan rendahnya kemampuan di sekolah dibandingkan dengan anak yang normal (25). Demikian juga dengan infeksi ISPA yang menunjukkan adanya hubungan signifikan dengan status gizi balita $(\mathrm{p}=0,00)$. Anak yang menderita ISPA berpotensi 5 kali lebih besar berstatus gizi kurus dibandingkan dengan anak tanpa infeksi ISPA.

Penelitian sebelumnya juga menunjukkan bahwa terdapat hubungan antara penyakit infeksi dengan kejadian kurang energi protein (KEP) pada balita di Kabupaten Demak Provinsi Jawa Tengah (26). Beberapa jenis penyakit infeksi erat kaitannya dengan kejadian KEP berat yaitu sebagai contoh diare dapat mengakibatkan dehidrasi yang mengancam jiwa, lama penyakit dan lama penyembuhannya juga dipengaruhi oleh keadaan gizi yang buruk. Kurang gizi dapat mempengaruhi penyakit menular, jika penyakit tidak dihentikan akan semakin parah sehingga dapat meningkatkan risiko kematian atau cacat permanen (27). Penyakit infeksi berpotensi sebagai penyokong atau pembangkit KEP. Penyakit diare, campak, dan ISPA kerap menghilangkan nafsu makan. Penyakit saluran pencernaan yang sebagian muncul dalam bentuk muntah dan gangguan penyerapan, menyebabkan hilangnya zat-zat gizi dalam jumlah besar. Percepatan 
proses katabolisme meningkatkan kebutuhan sekaligus menambah kehilangan zat-zat gizi (28).

Sesuai kerangka teori WHO, bahwa timbulnya malnutrisi secara langsung tidak hanya disebabkan oleh asupan makanan yang kurang, tetapi juga karena adanya penyakit infeksi. Sementara itu, pola pengasuhan anak merupakan penyebab sinergis atau penyebab tidak langsung terhadap timbulnya malnutrisi. Anak dengan pola pengasuhan yang baik dan mendapat asupan makanan cukup, tetapi sering menderita penyakit infeksi, maka anak dapat menderita kurang gizi (4). Dari berbagai penelitian telah diketahui adanya hubungan timbal balik antara gizi kurang dan berbagai penyakit infeksi. Dengan gizi kurang, daya tahan tubuh akan menjadi lemah dan memudahkan masuknya bibit penyakit. Sebaliknya, adanya penyakit infeksi menyebabkan nafsu makan menurun sehingga asupan makanan kurang, menurunnya absorbsi pada usus halus, meningkatnya katabolisme, dan berkurangnya zat gizi yang diperlukan untuk pembentukan jaringan dan pertumbuhan (29).

Hasil analisis multivariat menunjukkan bahwa variabel yang dominan berhubungan dengan status gizi balita adalah penyakit infeksi (ISPA, diare) dan asupan protein. Infeksi diare menunjukkan hubungan yang bermakna dengan status gizi balita $(\mathrm{p}=0,00 ; \mathrm{OR}=0,06)$. Artinya, anak tanpa infeksi diare memiliki risiko 0,06 kali lebih kecil menderita status gizi kurus dibandingkan dengan anak yang mempunyai riwayat infeksi diare. Penyakit diare merupakan salah satu penyakit yang berbasis lingkungan dan beberapa faktor yang dominan dalam penyebaran penyakit tersebut seperti sarana air bersih dan pembuangan tinja. Kedua faktor ini berinteraksi bersama dengan perilaku manusia. Apabila faktor lingkungan tidak sehat karena tercemar kuman diare serta berakumulasi dengan perilaku manusia yang tidak sehat yaitu melalui makanan dan minuman, maka dapat menimbulkan kejadian penyakit diare. Diare yang berlangsung beberapa waktu tanpa penanggulangan medis yang adekuat, dapat menyebabkan masalah gizi bahkan kematian karena kekurangan cairan yang mengakibatkan renjatan hipovolemik atau karena gangguan biokimia berupa asidosis metabolik yang lanjut (30).
Sementara itu, anak tanpa infeksi ISPA memiliki risiko 0,19 kali lebih kecil menderita status gizi kurus dibandingkan dengan anak yang mempunyai riwayat infeksi ISPA ( $p=0,00 ; O R=0,19)$. Keadaan gizi yang buruk muncul sebagai faktor risiko yang penting untuk terjadinya ISPA. Balita dengan gizi yang kurang akan lebih mudah terserang ISPA dibandingkan balita dengan gizi normal karena faktor daya tahan tubuh yang kurang. Penyakit infeksi sendiri akan menyebabkan balita tidak mempunyai nafsu makan dan mengakibatkan kekurangan gizi.

Variabel asupan energi dan pola asuh pada analisis multivariat menunjukkan hubungan yang tidak bermakna dengan status gizi balita meskipun pada analisis bivariat menunjukkan hubungan yang bermakna. Hal ini disebabkan adanya pengaruh variabel lain yang lebih kuat, mengingat variabel yang berpengaruh dianalisis sekaligus sehingga kemungkinan dikontrol oleh variabel yang lebih besar pengaruhnya yaitu penyakit infeksi. Variabel asupan protein setelah dianalisis secara multivariat menunjukkan adanya hubungan dengan status gizi balita $(\mathrm{p}=0,00$; $\mathrm{OR}=0,10$ ). Artinya anak dengan asupan protein cukup memiliki risiko 0,10 kali lebih kecil menderita status gizi kurus dibandingkan dengan anak yang mendapat asupan protein kurang. Protein merupakan salah satu zat gizi yang sangat dibutuhkan balita untuk pertumbuhan. Protein berfungsi untuk membangun dan memelihara sel-sel serta jaringan tubuh. Kekurangan protein pada balita dalam jangka waktu yang lama akan menyebabkan gangguan pertumbuhan. Manifestasi terburuk kekurangan protein adalah terjadinya kwashiorkor. Kwashiorkor umumnya terjadi pada anak-anak di bawah lima tahun (15).

Protein berfungsi sebagai pembentuk antibodi. Kemampuan tubuh untuk memerangi infeksi bergantung pada kemampuannya untuk memproduksi antibodi terhadap organisme yang menyebabkan infeksi tertentu atau terhadap bahan-bahan asing yang memasuki tubuh. Tingginya tingkat kematian pada anak-anak yang menderita gizi kurang kebanyakan disebabkan oleh menurunnya daya tahan tubuh terhadap infeksi karena ketidakmampuannya untuk membentuk antibodi. Dalam keadaan kekurangan protein, kemampuan tubuh untuk menghalangi pengaruh toksik bahan-bahan asing akan berkurang (31). 


\section{SIMPULAN DAN SARAN}

Penelitian ini menunjukkan bahwa sanitasi lingkungan berhubungan dengan kejadian penyakit infeksi pada balita dan dengan adanya penyakit infeksi akan berpengaruh pada status gizi balita. Disarankan kepada pemerintah setempat agar dapat meningkatkan intervensi terhadap faktor lingkungan untuk menurunkan angka kejadian ISPA dan diare pada balita seperti penyediaan sumber air minum yang bersih secara merata di seluruh wilayah kecamatan Tenggarong, penyediaan sarana pembuangan air limbah yang layak, dan mengaktifkan mobil pengangkut sampah hingga ke semua wilayah kecamatan Tenggarong. Petugas kesehatan sebaiknya memberikan penyuluhan tentang pentingnya sanitasi lingkungan keluarga, pentingnya pola asuh anak pada masa tumbuh kembang, dan perlu dilakukan penanganan medis secara adekuat pada penderita penyakit infeksi.

\section{RUJUKAN}

1. United Nations System Standing Committe on Nutrition. Accelerating the reduction of maternal and child undernutrition. Brazil: SCN News no.36; 2008.

2. Kementerian Kesehatan RI. Laporan riset kesehatan dasar. Jakarta: Badan Penelitian dan Pengembangan Kesehatan; 2013.

3. Dinas Kesehatan Kabupaten Kutai Kartanegara. Profil kesehatan Kabupaten Kutai Kartanegara tahun 20102013.

4. Soekirman. Ilmu gizi dan aplikasinya untuk keluarga dan masyarakat. Jakarta: Direktorat Jenderal Pendidikan Tinggi Depertemen Pendidikan Nasional; 2000.

5. Masangwi SJ, Morse TD, Ferguson NS, Zawdie G, Grimason AM, Namangale JJ. Behavioural and environmental determinants of childhood diarrhoea in Chikwawa, Malawi. Desalination 2009;248(1-3):684-91.

6. Dinas Kesehatan Provinsi Kalimantan Timur. Profil kesehatan Provinsi Kalimantan Timur tahun 2011-2013.

7. Lemeshow S, David WHJr, Janelle K, Stephen KL. Pramono D, Kusnanto H(Alih Bahasa). Besar sampel dalam penelitian kesehatan. Yogyakarta: Gadjah Mada University Press; 1997.

8. Gibson RS. Principles of nutritional assesment. New York: Oxport University Press; 2005.

9. Departemen Kesehatan RI. Pedoman teknis penilaian rumah sehat. Jakarta: Direktorat Jenderal PPM dan PL; 2002.

10. World Health Organization. WHO child growth standards length/height-for-age, weight-for-age, weight-for-length, weight-for-height and body mass index-for-age method and development. Genewa: WHO; 2006.

11. Departemen Kesehatan RI. Laporan riset kesehatan dasar Provinsi Kalimantan Timur tahun 2007. Jakarta: Badan Penelitian dan Pengembangan Kesehatan; 2008.

12. Muhilal JF, Hardinsyah. Penentuan kebutuhan gizi dan kesepakatan harmonisasi alam di Asia Tenggara. Prosiding Widya Karya Pangan dan Gizi VII; 2004; Jakarta.

13. Asrar M, Hadi H, Boediman D. Pola asuh, pola makan, asupan zat gizi dan hubungannya dengan status gizi anak balita masyarakat Suku Nuaulu di Kecamatan Amahai Kabupaten Maluku Tengah Propinsi Maluku. Jurnal Gizi Klinik Indonesia 2009;6(2):84-94.

14. Astannudinsyah. Pengaruh penyakit infeksi terhadap perubahan status gizi pada anak umur bawah dua tahun di Kabupaten Hulu Sungai Selatan [Tesis]. Yogyakarta: UGM; 2003.

15. Suhardjo. Pemberian makanan pada bayi dan anak. Kanisius: Yogyakarta; 2007.

16. Woldemicael G. Diarrhoea morbidity among young children in Eritrea: environmental and socioeconomic determinants. J Health Populat Nutr 2001;19(2):83-90.

17. Mulia RM. Kesehatan lingkungan. Yogyakarta: Graha Ilmu; 2005.

18. Checkley W, Epstein LD, Gilman RH, Cabrera L, Black RE. Effects of acute diarrhea on linear growth in Peruvian children. Am J Epidemiol 2003;157(2):166-75.

19. Soetjiningsih. ASI petunjuk untuk tenaga kesehatan. Jakarta: Penerbit Buku Kedokteran EGC; 1997.

20. Paryanto EP. Gizi dalam masa tumbuh kembang. Jakarta: Buku Kedokteran ECG; 1997.

21. World Health Organization. Global burden of disease estimates 2001. Genewa: WHO; 2002.

22. Parashar UD, Hummelman EG, Bresee JS, Miller MA, Glass RI. Global illness and deaths caused by rotavirus disease in children. Emerg Infect Dis 2003;9(5):565-72.

23. Tucker AW, Haddix AC, Bresee JS, Holman RC, Parashar UD, Glass RI. Cost-effectiveness analysis of a rotavirus immunization program for the United States. JAMA 1998;279:1371-6.

24. Niehaus MD, Moore SR, Patrick PD, Derr LL, Lorntz B, Lima AA, Guerrant RL. Early childhood diarrhea is associated with diminished cognitive function 4 to 7 years later in children in a Northeast Brazilian Shantytown. Am J Trop Med Hyg 2002;66:590-3.

25. Bethony J, Brooker S, Albonico M, Geiger SM, Loukas A, Diemert D, Hotez PJ. Soil-transmitted helminth infections: ascariasis, trichuriasis, and hookworm. Lancet 2006;367(9521):1521-32.

26. Suharsih. Hubungan pola asuh ibu dan penyakit infeksi dengan anak balita kurang energi protein di Kabupaten Demak Propinsi Jawa Tengah [Tesis]. Yogyakarta: UGM; 2001. 
27. Johansson K. Interaction effects of infection and malnutrition on child mortality in Scania, Sweden 17661894. Conference paper presented at the IUSSP; 28 September - 2 October 2009; Marrakech, Maroc.

28. Arisman MB. Gizi dalam daur kehidupan. Jakarta: EGC; 2004.
29. Brown KH. Diarrhea and malnutrition. J Nutr 2003;133(1):328S-32S.

30. Ngastiyah. Perawatan anak sakit. EGC: Jakarta; 2005.

31. Almatsier S. Prinsip dasar ilmu gizi.Jakarta: PT. Gramedia Pustaka Utama; 2009. 